\section{Income smoothing: a study of the health sector's credit unions}

\author{
Valéria Gama Fully Bressan \\ Douglas Coelho de Souza \\ Universidade Federal de Minas Gerais, Faculty of Economic Sciences, \\ Accouting Sciences Department, Belo Horizonte, Brazil

\section{Aureliano Angel Bressan} \\ Universidade Federal de Minas Gerais, Faculty of Economic Sciences, \\ Management Sciences Department, Belo Horizonte, Brazil
}

Received on

02/29/2016

Approved on

$04 / 19 / 2017$

Responsible editor:

Prof. Dr. Ivam Ricardo Peleias

Evaluation process:

Double Blind Review

\begin{abstract}
Purpose - The aim of this study was to verify whether the credit unions affiliated to Brazilian Confederation of Central Cooperatives (UNICRED) manage their accounting results, in order to reduce the variability of the institution's returns and transmit a sense of solidity to its members.
\end{abstract}

Design/methodology/approach - The method adopted was the Classic Linear Regression Model with Panel Data, estimated by Feasible Generalized Least Squares for fixed effects and corrections for heteroscedasticity. The sample was made up of 113 credit unions affiliated to UNICRED systems, over the 2001-2011 period, and data was made available by Central Bank of Brazil.

Findings - The analysis, carried out through non-discretionary results on credit operations in order to explain the changes in net expenses of provision on credit operations, indicated there was smoothing of results. Thus, we can infer that the credit unions affiliated to UNICRED make use of earnings management in the income smoothing modality.

Originality/value - This study contributes to the issue of Accounting Results Management, and corroborates that there are indications that, in the occurrence of higher non-discretionary results, credit unions tend to maximize provisions. Similarly, in the occurrence of lower non-discretionary results, they tend to minimize provisions, making evident the search for smaller variability in results, thus signaling mitigation of risks.

Keywords - Earnings management; income smoothing; credit unions; UNICRED; panel data.

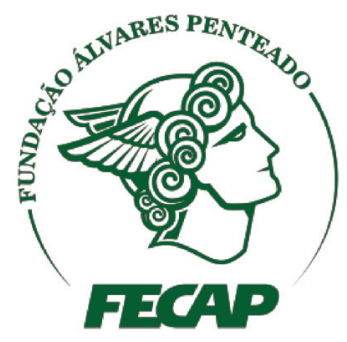

Review of Business Management

DOI: $10.7819 /$ rbgn.v0i0.2617 


\section{Introduction}

Credit unions are financial institutions formed through a cooperative society, with the purpose of providing financial services to their members, such as, for instance, the collection of demand and time deposits, checks, lending and the provision of collection services, and of custody, among others. Thus, credit cooperativism contributes considerably to regional economic growth by offering more viable alternatives to those who have less access to financial resources (Pinheiro, 2008).

Credit cooperativism is consolidated in the international scenario, and, in Brazil, it has been evolving considerably. From 2003 to 2013, there was an increase in membership from 1.9 to 7 million members. In December 2013, a total 1,154 credit unions were introduced in Brazil, of which 888 belonged to the systems of the largest Brazilian credit unions, which are the Cooperative Credit System of Brazil (SICOOB), the Cooperative Credit System (SICREDI), Brazilian Confederation of Central Cooperatives (UNICRED), Cooperative Urban Credit System (CECRED), the Cooperative System of Solidarity Economy (CONFESOL), and Uniprime Norte do Paraná (UNIPRIME) (Portal do Cooperativismo de Crédito, 2015).

These institutions do not have the purpose of earning profits, however, they must render accounts and provide their information to regulators, such as the Central Bank of Brazil (BACEN) and central cooperatives, in the case of individual credit unions. According to Maia, Bressan, Lamounier and Braga (2013), these obligations may pressure credit unions to manage their results in order to minimize the effect of fluctuations, since highly volatile results may indicate excessive risk exposure.

Creative accounting and earnings management are some of the expressions used when referring to the same phenomenon: management of results. According to Fuji and Carvalho (2005), earnings management is the handling of accounting results within the limits established by law, taking into account the discretion and subjectivity of accounting standards, without causing fraudulent accounting. In Brazil, Maia et al. (2013) sought to identify, in credit unions affiliated with the SICOOB, indications of earnings management to control capital adequacy, smooth results and avoid losses. The results found by Maia et. Al. (2013), point to the practice of earnings management to avoid disclosing losses and smoothing results, unlike capital adequacy, which did not influence discretionary accruals. In this same direction, Bressan, Bressan and Silva Júnior (2016) and Bressan, Bressan and Silva (2015) verified evidence of earnings management in credit unions affiliated to SICREDI, in the income smoothing modalities and to avoid disclosing losses. In this sense, this study assumes as research hypothesis that credit unions affiliated to UNICRED indicate earnings management in the income smoothing modality, since the UNICRED system is one of the three largest cooperative systems in Brazil, and the empirical results of the two other systems already researched by Maia et al. (2013) and Bressan et al. (2016) for the SICOOB and SICREDI systems, respectively, indicated signs of this type of accounting management.

In international literature, Hillier, Hodgson, Steveson-Clarke and Lhopadchan (2008), and Brown and Davis (2008), explored the issue of performance management in Australian credit unions, focusing on minimum capital requirement. The results found by Hillier et al. (2008) identified earnings management by credit unions that were at risk, seeking to gain time in the adequacy of the proportion of their net worth in relation to the assets weighted by the risk. Brown and Davis (2008) obtained different results from the study by Hillier et al. (2008). The use of Earnings Management was not identified; the possible explanation for this is the loyalty of its members, since credit unions present more advantageous options in relation to other financial institutions. Thus, according to these authors, 
pressure for better results can be met through other options, rather than Earnings Management (Brown \& Davis, 2008).

Since in international literature the inference about management of results in credit cooperatives is still inconclusive, and that in Brazil Earnings Management studies to assess the smoothing of results have indicated this practice for cooperatives affiliated with SICOOB and SICREDI, this article tries to answer the following research question: Do credit unions affiliated to UNICRED also use smoothing in their accounting results?

This research aims to analyze whether Brazilian credit unions affiliated to UNICRED manage their accounting results through the income smoothing modality. For analysis of the data, the classic linear regression model with panel data was used, based on the study of Maia et al. (2013). The data sample comprises observations from 113 credit unions affiliated to the UNICRED system, with data from the second quarter of 2001 up to the third quarter of 2011 . It should be noted that UNICRED affiliated credit unions are among the most efficient in Brazil, according to Gollo and Silva (2015).

The present study seeks, then, to fill the gap in the management of results for health sector credit unions in Brazil, since studies with this group of cooperatives were not detected with this approach. In addition, this study also generates subsidies for accountants who work in this branch of cooperativism. And, finally, it seeks to assess whether the proposition of Trueman and Tilman (1988) and Moyer and Shevlin (1995) - that reducing the fluctuation of results is beneficial to the institutions who adopt it -, also applies to credit unions affiliated with the UNICRED System.

\section{Theoretical framework}

\section{I Credit unions}

Credit unions are associations between persons which provide both supply and demand for resources, under their own legal form and nature. These cooperatives are qualified as financial institutions. However, earning profits is not the main objective of credit unions, but rather providing an alternative of access to microcredit and to financial services for the cooperative (Araújo \& Silva, 2011).

Credit unions differ from commercial banks for a number of reasons, as well as in their main objective - in the way services are provided, for example. Credit unions aim to provide personalized services, specific products for the demand of members, loans and financing with low interest rates, greater flexibility and speed of operations, meeting the needs of their members (Araújo \& Silva, 2011).

The first records of cooperativism date back to the $19^{\text {th }}$ century, when a pioneering group of 27 weavers gathered in the Rochadalle (Manchester) neighborhood and set up a consumer cooperative warehouse. Friedrich Wilhelm Raiffeisen pioneered in 1862 in Anhausen (now part of Neuwied) in Germany; this was the first rural credit cooperative. Raiffeisen is seen as one of the most important in the history of credit cooperativism, spreading its model of association to several countries such as Italy, France, Holland, England, and Austria, among others (Portal do Cooperativismo de Crédito, 2014).

In Brazil, the movement began in the city of Ouro Preto (MG) in 1889, with the creation of the first consumer cooperative, known as the Cooperative Society of Public Employees of Ouro Preto (Sociedade Cooperativa Econômica dos Funcionários Públicos de Ouro Preto). The records of the establishment of the first credit cooperative date back to 1902, in the city of Nova Petrópolis, in the state of Rio Grande do Sul, now called Pioneira. For many years, national legislation was subject to several changes, and only in 1964, with the regulation of credit unions, were they qualified in the same economic activity as commercial banks, as established by Law no. 4595 / 1964 (Diel, Diel, \& Silva, 2013).

Credit unions reached greater distinction through Law no. 5764 of December 16, 1971, 
which defined the National Cooperative Policy, established the legal regime of cooperative societies, and determined other measures; it was a regulatory framework for the sector, favoring its growth and consolidation (Law no. 5764, 1971).

In article 192 of Brazil's 1988 Federal Constitution, credit cooperatives were included in the National Financial System, giving them a new perspective as to the future. On April 17, 2009, the National Credit Cooperative System was updated through Complementary Law no. 130, and also through Resolution no. 4020/2011 and Resolution no. 4243/2013 (Supplementary Law no. 130, 2009; 4403, 2011, Resolution 4143, 2013).

Hillier et al. (2008) highlight the differences in background, philosophies and operational procedures between credit unions and other financial and banking intermediaries. The authors emphasize the philosophy adopted, which differs through the development of mutual collaboration, with the purpose of providing services to its members, based on the equitable treatment of members and the principles of cooperativism.

Credit unions traditionally presented conditions that restricted the entry of members, usually based on geographical boundaries and professional activities in the same area. However, with resolution 3.106 of June 2003, this situation has changed in Brazil; the creation of cooperatives with free admission of associates is now allowed.

These entities are not for profit; however, specific factors of the financial system may encourage cooperatives to improve their profitability, to meet market demands, including in their statements, which can be an important indicator of efficiency in relation to their membership ( Hillier et al., 2008).

Although credit unions are not for profit, there are internal and external pressures for them to present good results, and earnings management can be present as a consequence of this market demand (Maia et al., 2013).

\section{I.I Cooperativism in Brazil and the relevance of the UNICRED system}

From the establishment of the first Brazilian credit union in 1902, credit cooperativism has diversified and adapted to Brazilian standards, and is basically based on five cooperative systems: SICOOB, SICREDI, UNICRED, CECRED and CONFESOL. Included in other systems are UNIPRIME, CENTRALCRED and CECOOPES. In addition to these two groups, there are also credit unions that are not affiliated to any system; these are known as "independent", and represent $18 \%$ of the total number of credit unions (Portal de Cooperativismo de Crédito, 2015).

According to BACEN data from June 2014 in Brazil, credit unions managed about R\$ 186 billion of the total assets of financial institutions, ranking $6^{\text {th }}$ in the list of the largest financial institutions in the country. When analyzing equity over the same period, the amount reached $\mathrm{R} \$ 26.4$ billion, close to $\mathrm{R} \$ 28.4$ billion in Caixa Econômica Federal assets (Portal de Cooperativismo de Crédito, 2015).

Notably, credit unions have been contributing in large part to the growth of the National Financial System (NFS) in Brazil. In the first half of 2014, the growth in the amount of assets belonging to credit unions was $12 \%$, while the NFS registered a $4 \%$ increase. The volume of deposits and credit operations of the cooperatives increased $13 \%$ and $6 \%$, respectively, and the NFS showed a $2 \%$ increase in the amount of deposits and $4 \%$ in the amount of credit operations. When analyzing the market share, in the first six months of 2014, compared to December 2013, it can be observed that there was an increase in assets from $2.53 \%$ to $2.71 \%$, growth in the amount of deposits from $4.28 \%$ to $4.73 \%$, and credit operations increased from $2.75 \%$ to $2.78 \%$ (Portal de Cooperativismo de Crédito, 2015).

UNICRED Brazil was founded on July 11,1994 . It is made up of a set of cooperative financial institutions, with their own legal form and nature, regulated by the cooperative legislation 
and the National Financial System. UNICRED's membership includes health professionals such as doctors, pharmacists, veterinarians, psychologists and legal entities: medical labor cooperatives, hospitals, laboratories, clinics, among other health organizations (UNICRED, 2014).

The UNICRED system is among the largest cooperative credit systems in Brazil, operating in ten states of the federation plus the federal district, totaling, by December 2016, four UNICRED Centers, 34 cooperatives, 235 business units and a total 181,906 cooperatives (UNICRED, 2017). According to the ranking of the largest Brazilian credit cooperatives proposed by Silva, Padilha e Silva (2015), the credit unions affiliated to UNICRED obtained placements higher than those obtained by the ranking defined by the Central Bank of Brazil, which reinforces the importance of this system to Brazilian credit cooperativism.

UNICRED showed annual growth in several areas; from 2011 to 2015, for example, there was a $111.86 \%$ increase in total assets, $118.53 \%$ in the amount of loans and $106 \%$ in the company's capital stock. Although the number of cooperatives has shown a reduction to 34 cooperatives in 2016, UNICRED do Brasil's main functions are to politically and institutionally represent the system, establish guidelines and standardization, control and protection of the brand, as well as provide financial advice to UNICRED's credit unions (UNICRED, 2017).

\subsection{Earnings management}

According to Martinez (2006), earnings management has been widely discussed in the specialized press and in the international academic arena following the speech of SEC American Chairman Arthur Levitt entitled 'The Numbers Game' in 1998.

Accounting is ruled by rules and procedures, making the information generator follow a line of reasoning and procedures, improving the understanding of this science. The organizational characteristics of institutions are considered extremely relevant, capable of affecting the quality of the information reported by the companies (Arruda, Vieira, Paulo \& Lucena, 2015).

However, accounting legislation allows some arbitrariness in the choice of methods for producing information, and together with the stimuli of capital markets and the need to maximize wealth, this ends up to giving support to earnings management (Oliveira, Lemes, Almeida \& Ferreira , 2008).

According to Martinez (2013), the expression "earnings management" is used in Brazil to define the practice of discretionary use of accounting legislation by managers, in operational decisions, measurement, recognition and/or selection criteria for financial statements, within the limits permitted by accounting standards. In this way, these reports can influence the users of accounting, interfering in the decision making.

Profit management and creative accounting are some of the terms found in several surveys to represent the same accounting phenomenon, earnings management. Increasingly, this theme gains importance and study in the academic and professional setting, in an attempt to explain what this practice is more clearly.

According to Fuji and Carvalho (2005), Creative Accounting or Earnings Management is the management of accounting results practiced by managers and administrators, due to the discretion that accounting legislation offers. Accounting standards and principles give managers subjective interpretations, allowing the preparation of company statements according to their conveniences and aspirations. The great impasse of this practice is in the use of these limits of the law, where a manager can choose to defend their interests, and not to trustfully reflect the information to the various users, interfering in the decision making process.

To Rodrigues (2007), accounting has the function of providing transparent and qualified information to its users, obeying its accounting principles, and avoiding unjustifiable distribution 
of wealth. Accounting is then defined, as the main tool in the decision-making process of the various economic agents. In this way, Matsumoto and Parreira (2007) infer that companies' results are one of the products used by the users of financial statements to measure economic and financial health, operational performance and aid in the decision-making process.

Thus, the earnings management phenomenon encompasses controversial issues related to the basic principles of accountants, such as conscientious use of concepts of objectivity, faithful image, principles of revenue realization and confrontation with expenses, ethics and subjectivism (Matsumoto \& Parreira, 2007). When any of these principles is circumvented, or when the limits prescribed by accounting legislation are violated, the accounting and the information generated becomes fraudulent.

According to Dechow and Skinner (2000), fraudulent accounting is the practice where clearly the manager's intention to deceive the stakeholders can be observed, beyond the limits of the law, as opposed to the earnings management. The author also cites some obvious examples of fraudulent accounting, such as: recognition of sales before they occur, generation of fictitious sales and estimate inventory erroneously through fictitious accounts.

According to Matsumoto and Parreira (2007), some issues motivate managers to practice Earnings Management, such as the pressure exerted by the market for better results, a desire to attract new investors, maximize profits, among many other causes that seduce managers to opt for this method. It is also evident that the great majority of causes are linked to the continuity of the enterprise, which is important for the user, from the point of view of the expected return on investment.

Taking into consideration the various motivations involved, there are several types of Earnings Management, where you can highlight three main ones: target earnings, which would be the management of the accounting results to increase or decrease profits; Income smoothing, management to reduce the variability of accounting results, avoiding oscillations; and Big Bath Accounting, which aims to manage results to reduce current profit in order to increase future profitability (Martinez, 2001).

According to Trueman and Titman (1988), the management of accounting results through the income smoothing modality will always have a beneficial character for the institutions, since it reduces the cost of capital, considering that companies with lower variability in results, show signs of stability and are viewed with greater confidence by investors.

In order to perform the Earnings Management, some transactions are commonly used. Kraemer (2005), cites some examples: increase or reduction of expenses, due to the ease that accounting standards provide to handle accounts such as amortization periods and depreciation of assets, in order to ease of changing the period's expenses; the increase or decrease of revenues, since it is possible to anticipate or delay the recognition of revenues, with the basic principles being the conservatism convention and the comparison of revenue expenses; and increase or decrease of assets, through techniques of alternation of valid methods to evaluate the cost of inventories, as well as the handling of revenues and expenses, already mentioned, impacting the value of the asset.

In this way, two important mechanisms are called for earnings management: management through accruals and operational decisions. Martinez (2001, p. 16) defined accumulations as "the difference between net income and net cash flow", since in practical terms, revenue can be recognized without effective cash inflow. There is nothing wrong with registering accumulations, 
but the manager can use his discretion to increase or decrease accumulations for reasons unrelated to the reality of the business, in order to influence profit (Martinez, 2008).

Martinez (2006) investigated whether Brazilian companies promoted the management of accounting results with the intention of reducing their variability in the period from 1995 to 1999, and found that when decisions are made regarding recognition of expenses, the variability of accounting results, and noted that: i) depreciation expenses, expenses with allowance for doubtful accounts and non-operating revenues were used to reduce the variability of accounting results; And that (ii) changes in the amortization of goodwill or goodwill on investments, provision for losses on investments and revaluation reserves are correlated with actions to reduce the variability of results ${ }^{1}$.

Reis (2014) defines that management through operational decisions, unlike accruals, occurs when the managers handle the activities directly linked to the operations of the company, in order to reach results goals. As an example, discount practices are mentioned, to increase the number of sales in the current month and the increase in the scale of production, in order to reduce the cost of the products.

Earnings management is already a subject known to researchers, but creating accurate documents about it is not an easy task. The difficulty begins in identifying which statements were managed, requiring that the results be estimated before handling. A common attempt to arrive at the evidence of this practice is to identify the likely motivations of managers and then to compare these motivations with the more inconsistent results (Healey \& Wahlen, 1999).

Economic and financial market structures are becoming increasingly complex, requiring a more qualified work of accounting; at the same time, managers are pressured to always obtain better results, making their activity attractive to the investor. These are factors that cause administrators to manage the results of their entity, purposely altering their image. As Matsumoto \& Parreira (2007) argue that management of results is legal due to the gaps that accounting legislation confers on managers, this practice has been the subject of discussion by regulators and, mainly, its consequences.

\subsection{Empirical studies on earnings management in financial institutions and credit unions}

This section intends to report some empirical studies of several authors, in the area of earnings management applied in financial institutions and credit unions, evidencing the type of company studied, its objective and its main conclusions.

In relation to market performance, Martinez (2001) emphasizes that Brazilian companies that manipulate their results "artificially" can achieve good results and attract investors in the short term. However, when this practice is identified in the long run, the actions are penalized with the worst performances accumulated.

In order to analyze the earnings management in financial institutions located in Brazil, Fuji and Carvalho (2005) empirically studied whether the allowance for doubtful accounts $\left(\mathrm{PCLD}^{1}\right)$ influences this practice. Since the main activity of these institutions is the granting of credits, the PCLD makes up an important part in the design of credit risk at appropriate levels. The period of analysis is between 1999 and 2003, after the validity of the resolution of $2.682 / 99$, which established new criteria for the classification of credit operations.

Fuji and Carvalho (2005) used the analysis of the Pearson correlation coefficient, analysis of the specific accounts and the model of discretionary accumulations. The specific analysis of the PCLD account showed a positive correlation between this and the results of financial institutions. The application of the Jones model, adapted to the financial institutions scenario, showed a contradictory relationship 
between PCLD expenses and cash flow, as well as a high positive correlation between PCLD expenses and discretionary accumulations, showing signs of earnings management.

In order to verify whether financial conglomerates operating in Brazil use the allowance for doubtful accounts, the unrealized gains or losses on the Securities to manage their results, Zendersky (2005) used the estimation of a two stage econometric model to verify this relationship. The study analyzed the financial institutions operating in the National Financial System, from March 2000 to December 2004, with a sample of 53 companies. The results found by the author showed a positive relationship in the practice of Earnings Management, through the PCLD and unrealized gains or losses on securities. Goulart (2007) used correlation and regression techniques to identify whether Financial Institutions operating in the Brazilian market make use of accounting for credit operations, securities and derivatives for the purpose of earnings management. With a sample of the 50 largest financial institutions in Brazil, covering the period from June 2002 to December 2006, the survey identified that financial institutions use these means to manage their accounting results.

In international literature, studies by Hillier et al. (2008) and Brown and Davis (2008), addressed the issue of performance management in Australian Credit Unions, having as main analytical data the minimum capital requirement. These authors prove that there is no convergence in the results of the research, even though it is treated in the same country and evaluated the same practice.

To identify whether Australian Credit Unions have used earnings management after the introduction of the Australian Financial Institutions Code (AFIC) capital requirement rules, Hillier et al. (2008), used a sample of 137 credit unions, covering the period from July 1987 to December 1994 . The results found that credit unions that were at risk used Earnings Management to gain time in adequacy on the proportion of their net equity in relation to riskweighted assets, due to the fact that they were forced to adjust their capital/risk ratio.

Brown and Davis (2008) found divergences compared to the study by Hillier et al. (2008). Australian Credit Unions were also used, covering the period from 1992 to 2004, following the implementation of minimum capital requirements. The authors identified that, to some extent, with the loyalty of their associates, and generally presenting the best rates in credit operations, cooperatives would be able to improve the profitability of their portfolios in the face of pressure for better performance, without the usage of earnings management practices.

Dantas, Medeiros, Galdi and Costa (2013), carried out empirical studies on the practice of Earnings Management in financial institutions operating in the Brazilian market through the use of securities. Using a two stage model, the survey comprised the period from the third quarter of 2002 to the fourth quarter of 2010, and identified that there is discretionary action by managers in the valuation of securities exchange (TVM).

In order to investigate whether Brazilian financial institutions use the management of results through the execution of securitization operations, Camara and Galdi (2013) used the regression of panel data for the application of the analytical model. The results found confirm the international literature, according to Dechow, Myers and Shakespeare (2010), that managers use the discretion present in securitization transactions to smooth the results of financial institutions.

To analyze whether credit cooperatives in Brazil linked to SICOOB managed their results to control capital adequacy, smooth results and avoid spreading losses, Maia et al. (2013), are based on the period between the first quarter of 2001 and the third quarter of 2011 , to carry out the study.

The results found by Maia et al. (2013), point out that capital adequacy is not the factor that exerts the greatest influence on discretion 
over accruals. However, the hypotheses of profit smoothing and management to avoid reporting losses were not rejected, demonstrating evidence of earnings management, since they are extremely important variables for single credit unions.

Bressan et. al. (2016) evaluated whether earnings management practices, specifically with the use of the income smoothing technique, have occurred in Brazilian credit unions belonging to SICREDI, based on the period between the first half of 2001 and the second half of 2011.

The results found by the authors showed that the credit unions affiliated to the SICREDI system managed their results in the income smoothing modality in the period studied, through the net expense account of provisions for credit operations to smooth results.

In another study, Bressan et al. (2015) evaluated the management of results to avoid disclosing losses in credit unions affiliated to SICREDI, and one can infer the occurrence of this type of management of results in these cooperatives.

\section{Research methods}

\section{I Analytical model}

The analytical model applied to this research was based on the study done by Maia et al. (2013), with adaptations to the market and the reality of Brazilian cooperativism, also used by Santos (2007), based on models proposed by Ahmed, Tekeda and Thomas (1999).

The hypothesis to be tested is whether the credit unions of Brazil, affiliated to the UNICRED system, make use of the practice of Earnings Management in the income smoothing modality. For this analysis, it used the variable Non-Discretionary Result (RNDoc), which is the result before expenses net of provisions, divided by total credit operations. To test the hypothesis, we estimated the following model:

$$
\begin{aligned}
\operatorname{VDLoc}_{i t}= & \beta_{0}+\beta_{1} L A_{i t}+\beta_{2} T A_{i t}+\beta_{3} V O C_{i t}+\beta_{4} I P C A_{i t} \\
& +\beta_{5} \text { RNDoc }_{i t}+\beta_{6} \text { Data }_{i t}+c_{i}+\varepsilon_{i t}
\end{aligned}
$$

In which:

VDLoc $=$ Change in net expenses with provisions for loan operations, divided by the volume of loan operations at the beginning of the period;

$\mathrm{LA}=$ Binary variable for "free admission" cooperatives, assuming value $1 \mathrm{for}$ free admission cooperatives and 0 , for otherwise;

$\mathrm{TA}=$ Age of credit union in years;

$\mathrm{VOC}=$ Variation in volume of credit operations;

IPCA = Brazil's Broad Consumer Price Index;

RNDoc = Income before expenses, net of provisions, divided by total credit operations for this valuation.

Data $=$ Represents the quarterly trend and captures the trend of the dependent variable.

$\mathrm{c}_{\mathrm{i}}=$ Error component that indicates the specific individual non observable effect, which differs between cooperatives (i), and is invariant in time.

$\varepsilon_{\mathrm{it}}=$ The so-called "usual" error of the regression, which varies between cooperatives (i) and time ( $\mathrm{t}$ ).

The dependent variable used in the model is the Change in net expenses with provisions for credit operations (VDLoc). This variable is widely used in several models to identify Earnings Management in financial institutions, as in the studies of Goulart (2007) and Santos (2007), because they are considered as one of the biggest accruals ${ }^{2}$ in the sector, as described by Ahmed et al. (1999).

According to Maia et al. (2013), the variable VOC (variation of credit operations), is one of the most significant assets for credit 
cooperatives, because they perform financial intermediation between savers and borrowers. According to Goulart (2007), the larger the volume of credit operations, the greater the provision for operations is expected to be, and a positive signal is expected for the parameter of this variable.

The macroeconomic variable IPCA (broad consumer price index) was used as the control variable. It is expected that the IPCA will have a positive coefficient, since a possible increase in inflation variation generates an increase in the provision for loan losses, influencing a higher level of default (Santos, 2007).

A positive signal for RNDoc is expected, since, when it grows, the expectation is that there is also an increase in net provision expenses, in view of the decrease in profit and the smoothing of the final result. On the other hand, when there is a decrease in RNDoc, the incentive is to reduce VDLoc (Maia et al., 2013 p. 104).

Thus, there is evidence of Earnings Management, according to the models used by the authors Martinez (2001), Ahmed et al. (1999), Goulart (2007) and Maia et al. (2013).

\subsection{Operational procedures for estimation of the panel data model}

For the estimation of the panel data model, we followed the suggestion of Bressan, Braga, Bressan and Resende Filho (2012), which emphasize that it is necessary to follow a series of steps, so that it is estimated by the most appropriate model. The first procedures to be followed is the estimation of pooled OLS and fixed effects, to then test one against the other via Chow test ( $\mathrm{F}$ test), with the null hypothesis that the Pooled model is preferable to fixed effects. Then, the analytical model is estimated through the random effects specification, and by using the Breusch-Pagan test (Lagrange Multiplier test), it is verified which of the models is the most appropriate: the pooled model $\left(\mathrm{H}_{0}\right)$ or the model Random effects $\left(\mathrm{H}_{1}\right)$. The next step is to verify, through the Hausman test, whether the null hypothesis that the random effects model estimator is preferable to the fixed effects estimator, because the former is consistent and efficient, while the latter is only consistent.

After the previous tests were carried out, we found that the fixed-effects model is preferable to the random-effects model, followed by the statistical validation of the model via Wooldridge tests, to test the autocorrelation of the errors, and for heteroscedasticity by a Wald test. Finally, heteroscedasticity was confirmed, then the fixed-effect model was estimated again by FGLS (Feasible Generalized Least Squares) considering corrections for heteroscedasticity. Also, multicollinearity was evaluated by the Variance Inflation Factor (FIV) test. Finally, the F-ANOVA statistic that confirms the validity of the model for inferences was used.

\subsection{Sample and data}

The present study uses an unbalanced panel with 4,434 observations from 113 credit unions affiliated to the UNICRED system, founded between 1991 and 2008, with data from the second quarter of 2001 to the third quarter of 2011. This sample represents $71 \%$ of credit unions affiliated to Unicred during the study period. Capital-loan cooperatives, central cooperatives and cooperatives with missing information were excluded from the study. Data was provided by the Central Bank of Brazil, and due to the fact that it contains information from the Accounting Plan for Institutions of the National Financial System (COSIF) that is confidential and not publicly available, obtaining them was only possible following that institution's permission.

\section{Results}

Table 1 shows the descriptive statistics of the variables used in the estimation of the model, referring to the 113 credit unions affiliated to the UNICRED system of the sample, comprising the period from the second quarter of 2001 to the third quarter of 2011. 
Table 1

Descriptive statistics of the variables used in the estimated model - UNICRED System, for the period from the 2nd quarter of 2001 to the 3rd quarter of 2011.

\begin{tabular}{lccccc}
\hline Statistic & VDLoc & VOC & TA & RNDoc & IPCA \\
\hline Minimum & -0.201225 & -0.971217 & 3 & -16.9831 & 100 \\
Maximum & 1.49706 & 1747.76 & 20 & 1643.64 & 196.361 \\
Median & 0.0026365 & 0.0534455 & 15 & 0.032241 & 151.56 \\
Mean & 0.0056152 & 0.5060719 & 14.71042 & 0.4125946 & 148.3644 \\
Std. Deviation & 0.0360935 & 26.28304 & 3.234785 & 24.68784 & 26.80554 \\
Coef. of Variation & 6.427795 & 51.93537 & 0.2198975 & 59.83559 & 0.1806737 \\
\hline
\end{tabular}

Source: Research Results

The above table presents an average of $0.0056(0.56 \%)$ in the dependent variable VDLoc, with standard deviation equal to 0.0361 , resulting in a high coefficient of variation in the value of 6.4278. This indicates a large heterogeneity of this variable in credit unions affiliated to UNICRED over the 2001-2011 period, which will be used to verify the smoothing of results. The median is 0.0026 , which means that in half of the observations the net expenditure on loans increased by more than $0.26 \%$ in relation to the total credit operations of the previous period. The minimum presented a negative value of 0.12012 , which indicates a reduction in net provision expense; that is, a higher volume of reversals than provision expenses.

The VOC variable, which indicates the variation in credit operations between the quarters $t$ and $t-1$, presented a median of 0.0534 and an average of 0.5060 , that is, on average, credit operations increased by $50.6 \%$ per quarter. The coefficient of variation, in the value of 51.9353, also indicates a great heterogeneity of this variable.

In relation to the activity time of the cooperatives (TA), there are observations of 3 to
20 years of operation authorization. From the median, it can be seen that $50 \%$ of UNICRED affiliated cooperatives presented up to 15 years of activity during the analyzed period.

The variable RNDoc had a mean of 0.4125 and a median of 0.0322 . It also shows a minimum of -16.9831 and the maximum of 1643.64. The coefficient of variation, in the amount of 59.83559, also shows heterogeneity in the results, indicating the diversity of the UNICRED system in relation to the result of the credit unions.

Table 2 shows the results of the model estimation with panel data, in order to evaluate if the Brazilian cooperatives affiliated to the UNICRED System smoothed the results through the net expenses of provision for credit operations, in the period between March 2001 and September 2011. The estimation was made by Feasible Generalized Least Squares (FGLS), assuming fixed effects, generated through Stata ${ }^{\oplus}$ software, considering only the heteroscedasticity problem detected in the operational procedures. 


\section{Table 2}

Results of the panel-based model estimation to assess whether UNICRED cooperatives used net expenses from provisions for credit operations to smooth results in the period between March 2001 and September 2011

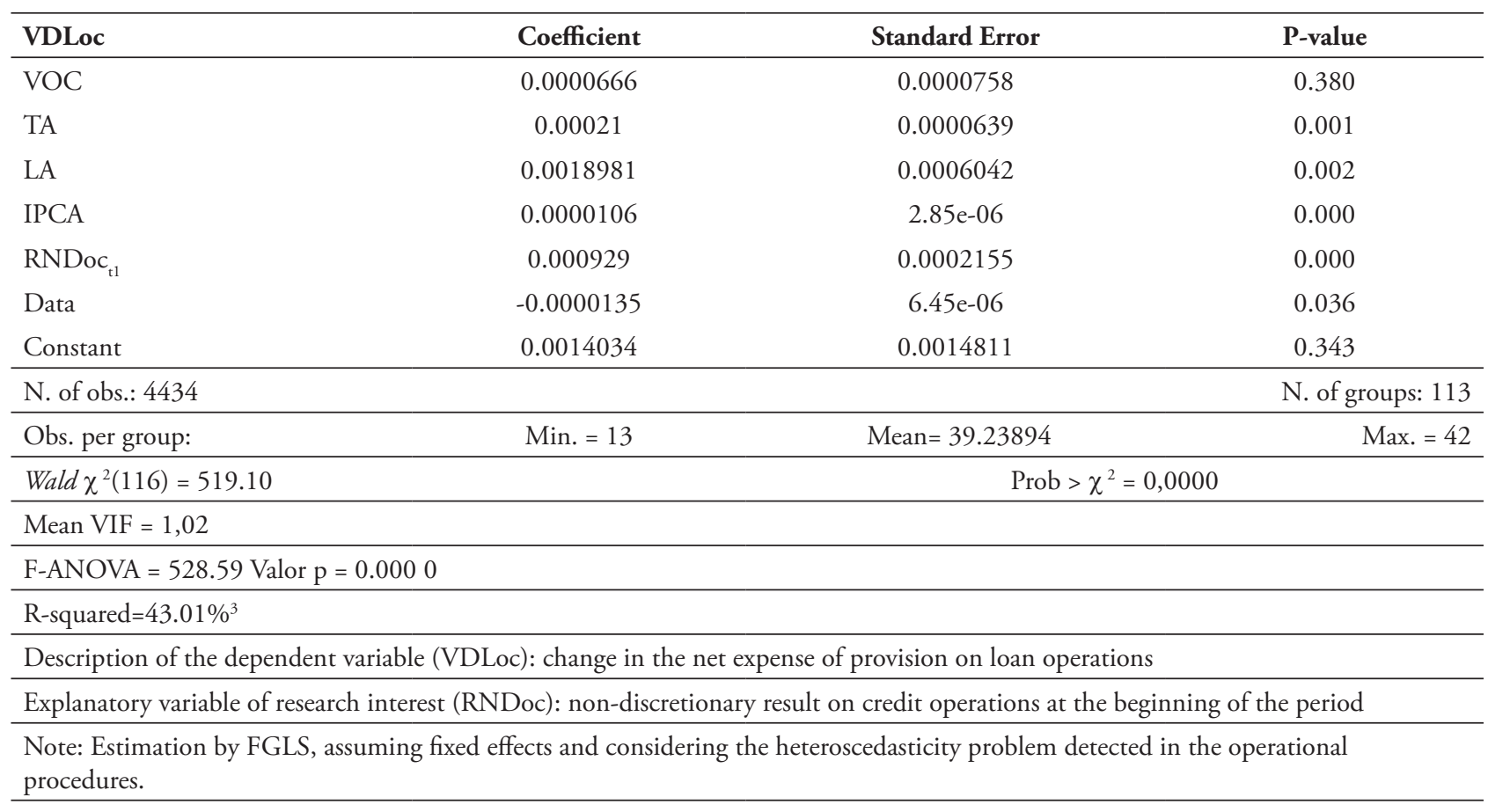

Source: Research results

The VOC variable was not statistically significant in the model, assuming a significance level of $\alpha=5 \%$. This result corroborated with the results obtained for credit unions affiliated with the SICREDI System, according to a study by Bressan et al. (2016). On the other hand, this diverged from the studies of Goulart (2007) and Maia et al. (2013), which verified that the larger the volume of credit operations, the greater the VDLoc.

The variable TA was also statistically significant in the model, at $\alpha=5 \%$, with a positive sign, which means that the longer the company has the greater the change in net expenses with provisions for credit operations (VDLoc). This result coincides with that found by Bressan et al. (2016) applied to credit unions affiliated with SICREDI.

The LA dummy variable was statistically significant in the estimated model, corroborating the results found by Bressan et al. (2016) for cooperatives affiliated to SICREDI, and diverged in relation to the Sicoob system researched by Maia et al. (2013). This result is consistent with the expectation that the transformation to free admission increases to a certain degree the credit portfolio risk according to Amaral and Braga (2008).

The IPCA showed a positive coefficient, as expected, as a possible increase in inflation variation, leads to an increase in the provision for losses on loan operations, influencing a higher level of default.

The variable "date" represents the quarterly trend and captures the trend of the dependent variable, was significant at $5 \%$, and indicates that the change in the net provisioning expense on loan operations presented a decreasing trend over the period from 2001 to 2011.

This study offers the RNDoc as an explanatory variable of interest, with the purpose of verifying indications that the cooperatives linked 
to UNICRED manage their accounting results. The variable was statistically significant at $\alpha=1 \%$ to explain changes in net provision expense. The coefficient shows a positive sign, which means that the larger the RNDoc, the higher the VDLoc, indicating that the cooperatives used UNICRED, the net provisioning expenses to soften the results. The result corroborates the studies of Maia et al. (2013) and Bressan et al. (2016), which identified indications of management of results through the net expenses of provisions for credit operations, by Brazilian credit cooperatives affiliated to the SICOOB and SICREDI systems, respectively.

Just as in this study, the results obtained for Earnings Management (GR) in the smoothing of results are similar to the findings in Fuji and Carvalho (2005), Zendersky (2005), Goulart (2007), Dantas et al. (2013) and Camara and Galdi (2013) applied to financial institutions operating in Brazil. Domingos et al. (2013) found indications of GR in the income smoothing modality, in the companies listed on the BM\&FBovespa stock exchange, through specific accounts. And, applied to credit unions, Maia et al. (2013) and Bressan et al. (2016), also verified the occurrence of GR in the income smoothing modality in SICOOB and SICREDI, respectively

According to Moyer and Shevlin (1995) and Trueman and Titman (1988), managing income through income smoothing is one of the most common management practices. These authors see this procedure positively, since it allows the institution to create shareholder value, considering that companies with lower profit variability will generate a lower perception of risk, and consequently a lower cost of capital. Although credit unions did not have the same objective as traditional financial institutions, the perception of risk perception was similar among these institutions, according to the results obtained in this research.

\section{Conclusions}

One of the most important products in the universe of accounting for users is the result earned by the company (profit/loss). Often this number serves as the basis for performance analysis of entities. However, part of this result can be originated by accounting adjustments of discretionary nature, influenced by situations exogenous to the company, leading to the phenomenon of Earnings Management (Martinez, 2006).

The present study had as objective to identify if credit unions affiliated to the UNICRED system, used accounting practices in the income smoothing modality. The sample consisted of 4,434 observations from 113 credit unions of the UNICRED system, founded between 1991 and 2008, with data from the second quarter of 2001 to the third quarter of 2011. Capital-loan credit unions were excluded from this sample, along with credit unions with missing information.

The study was based on results generated by the estimation of a Linear Regression Model with Panel Data, with the dependent variable being the variation in net expenses with provisions for credit operations (VDLoc), and using the variable Non-Discretionary Result (RNDoc). After application of the model, it was shown that cooperatives affiliated to UNICRED used, in the period studied, the expenses net of allowances for loan operations, to soften the results, indicating that the greater the non-discretionary result on loans, the greater the variation in the net expense of provision tends to be.

The result found in the current research is consistent with the study by Maia et al. (2013), for cooperatives affiliated with SICOOB, and with the work of Bressan et al. (2016) applied to SICREDI cooperatives. Thus, there are indications that in the occurrence of higher nondiscretionary outcomes, credit unions tend to maximize provisions, and in the occurrence of lower non-discretionary outcomes, they tend to minimize provisions, making evident the search for a lower variability in results.

Credit unions may be pressured to soften the results because their accounting information 
is regularly monitored by both the BACEN (supervisory body) and central cooperatives. In this way, results of small fluctuations are relevant for these entities, since volatility in them can indicate a risk exposure scenario (Maia et al., 2013).

It is also important to point out that the management of results is a practice that is foreseen within the legal accounting limits, that is, the discretion of the rules is exercised in order to influence the interpretation and, consequently, the decision-making of the users - unlike accounting fraud, which is considered a crime and faces penalties provided by law.

As seen previously, credit unions have an important social role, by facilitating access to financial resources for economic agents that lack quality financial alternatives. Although these cooperatives are non-profitable, they tend to have the remains of trust and stability. Therefore, it is concluded that cooperatives tend to deal responsibly and cautiously with accounting presentations to their associates, supervisors, central cooperatives, and the Central Bank, as discussed by Maia et al. (2013).

The results found in the present study are restricted to the sample used by UNICRED cooperatives. It is suggested to evaluate whether other credit unions, as well as credit unions not affiliated with some system, known as independents also make use of accounting discretion to manage their results.

\section{Notes:}

1 Currently, there is no longer the Allowance for Doubtful Accounts (PCLD) for non-financial institutions. The financial institutions, other institutions authorized to operate by the Central Bank of Brazil and the consortium administrators, must comply with Technical Pronouncement CPC 25 and be in agreement with Accounting Plan for Institutions of the National Financial System (COSIF), for provisions of credit operations.

2 Accruals: According to Martinez (2001), accruals are income accounts that enter into the profit calculation, but do not necessarily imply a change in cash equivalents, resulting in the difference between net income and net operating cash flow.

3 Greene (2008, p. 156) points out that the use of R2 becomes inconsistent for the comparison and analysis of the fit quality of models estimated by Generalized Least Squares. The author suggests using the square of the correlation between the values predicted by the model and the observed values as a possible representative of the fit quality of the model. In this way, the R2 information in the table is calculated as Greene.

\section{References}

Ahmed, A. S., Takeda, C., \& Thomas, S. (1999). Bank loan loss provisions: A reexamination of capital management, earnings management and signaling effects. Journal of Accounting \& Economics, 28(1), 1-25.

Amaral, I. C., \& Braga, M. J. (2008). A influência dos riscos de liquidez e de crédito no processo de conversão das cooperativas de crédito rural em cooperativas de crédito de livre admissão: Um estudo de caso. Revista de Contabilidade e Organizaçôes, 2(4), 26-147.

Araújo, E. A. T., \& Silva, W. A. C. (2011). Cooperativas de crédito: A evolução dos principais sistemas brasileiros com um enfoque em indicadores econômico-financeiros. Revista Contemporânea de Economia e Gestão, 9(1), 117-126.

Arruda, M. P., Vieira, C. A. M., Paulo, E., \& Lucena, W. G. L. (2015). Análise do conservadorismo e persistência dos resultados contábeis das instituiçôes financeiras brasileiras. Sociedade, Contabilidade e Gestão, 10(2), 23-25.

Bressan, V. G. F., Braga, J. M., Bressan, A. A., \& Resende, M. A., Fo. (2012). O seguro depósito induz ao risco moral nas cooperativas de crédito brasileiras? Um estudo com dados em painel. Revista Brasileira de Economia, 66(2), 167-185.

Bressan, V. G. F., Bressan, A. A., \& Silva, J. M., Jr. (2015). Evitar Divulgar Perdas: Foi Uma Estratégia Utilizada na Última Década pelas Cooperativas de Crédito Filiadas ao Sicredi?. Sociedade, Contabilidade e Gestão, 2(3), 27-42

Bressan, V. G. F., Bressan, A. A., \& Silva, J. M., Jr. (2016). Gerenciamento de resultados 
em cooperativas no Brasil: Avaliação do income smoothing às filiadas ao Sicredi. Advances in Scientific and Applied Accounting, 9(3), 283-300.

Brown, C., \& Davis, K. (2008). Capital management in mutual financial institutions. Journal of Banking \& Finance, 33(3), 443-445.

Camara, G. A., \& Galdi, F. C. (2013). Securitização como mecanismo de gerenciamento de resultados em bancos brasileiros. Revista de Contabilidade e Organizaçóes, 7(18), 14-24.

Dantas, J. A., Medeiros, O. R., Galdi, F. C., \& Costa, F. M. (2013). Gerenciamento de resultados em bancos com uso de TVM: Validação de modelo de dois estágios. Revista Contabilidade \& Finanças, 24(61), 37-54.

Dechow. P. M., \& Skinner, D. (2000). Earnings management: Reconciling the views of accounting academics, practitioners and regulators. Accounting Horizons, 2(14), 235-250.

Dechow, P. M., Myers, L., \& Shakespeare, C. (2010). Fair value accounting and gains from asset securitizations: A convenient earnings management tool with compensation sidebenefits. Journal of Accounting and Economics, 49(1-2), 2-25.

Diel, F. J., Diel, E. H., \& Silva, T. P. (2013). Análise da rentabilidade e o posicionamento do ranking das cooperativas de crédito do Brasil. Anais do Encontro Nacional da Associação Nacional de Programas de Pós-Graduação em Administração, Rio de Janeiro, RJ, Brasil, 37. Retrieved from http://www.anpad.org.br/admin/pdf/2013_ EnANPAD_CON959.pdf

Domingos S, R. M., Lima. S. M. \& Ponte, V. M. R. (2013). Income smoothing: Um estudo após a adoção do IFRS no Brasil. Contextus Revista Conteporânea de Economia e Gestão, 11(2),181199.

Fuji, A. H., \& Carvalho, L. N. G. (2005). Earnings management no contexto bancário brasileiro. Anais do Congresso USP de Contabilidade $e$ Controladoria, São Paulo, SP, Brasil, 5. Retrieved from http://www.congressousp.fipecafi.org/anais/ artigos52005/7.pdf

Gollo, V., \& Silva, T. P. (2015). Eficiência global no desempenho econômico-financeiro de cooperativas de crédito brasileiras. Revista de Contabilidade e Organizaçóes, 9(25), 44-55.

Goulart, A. M. C. (2007). Gerenciamento de resultados contábeis em instituiçôes financeiras no Brasil (Tese de doutorado). Faculdade de Economia, Administração e Contabilidade, Universidade de São Paulo, São Paulo, SP, Brasil.

Greene, W. H. (2008). Econometric Analysis (6 ${ }^{\text {th }}$ ed.). United States: Pearson.

Healy, P. M. \& Wahlen, J. M. (1999). A review of the earnings management literature and its implications for standard settings. Accountings Horizons, 13(4), 365-383.

Hillier, D., Hodgson, A., Stevenson-Clarke, P., \& Lhaopadchan, S. (2008). Accounting window dressing and template regulation: A case study of the Australian credit union industry. Journal of Business Ethics, 83(3), 579-593.

Kraemer, M. E. P. (2005). Contabilidade criativa: Maquiando as demonstrações contábeis. Pensar Contábil, 7(28), 1-13. Recuperado de http://www.spell.org.br/documentos/ ver/21810/contabilidade-criativa--maquiandoas-demonstracoes-contabeis/i/pt-br

Lei n. 5.764, de 16 de dezembro de 1971. Define a política nacional de cooperativismo, inclui o regime jurídico das sociedades cooperativas e dá outras providências. Recuperado de http://www. planalto.gov.br/ccivil_03/leis/L5764.htm

Lei n. 130, de 17 de abril de 2009. Dispóe sobre o Sistema Nacional de Crédito Cooperativo e revoga dispositivos das Leis nos 4.595, de 31 de dezembro de 1964 , e 5.764 , de 16 de dezembro 
de 1971. Retrieved from http://www.planalto.gov. br/ccivil_03/leis/lcp/Lcp130.htm

Maia, S. C., Bressan, V. G. F., Lamounier, W. M., \& Braga, M. J. (2013). Gerenciamento de resultados em cooperativas de crédito no Brasil. Brazilian Business Review, 10(4), 96 - 116.

Martinez, A. L. (2001). "Gerenciamento" dos resultados contábeis: Estudo empírico das companhias abertas brasileiras (Tese (Doutorado). Faculdade de Economia, Administração e Contabilidade, Universidade de São Paulo, São Paulo, SP, Brasil.

Martinez, A. L. (2006). Minimizando a variabilidade dos resultados contábeis: Estudo empírico do Income smoothing no Brasil. Revista Universo Contábil, 2(1), 9-25.

Martinez, A. L. (2008). Detectando Earnings management no Brasil: Estimando os accruals discricionários. Revista Contabilidade \& Finanças, 19(46), 7-17.

Martinez, A. L. (2013). Earnings management in Brazil: A survey of the literature. Brazilian Business Review, 10(4), 1-29.

Matsumoto, A. S., \& Parreira, E. M. (2007). Uma pesquisa sobre o gerenciamento de resultados contábeis: Causas e consequências. UNB Contábil, 10(1), 141-157.

Moyer, A. \& Shevlin, C. (1995). Income smoothing and incentives: Empirical test. The Accounting Review, 62(2), 358-377.

Oliveira, V. A., Lemes, S., Almeida, L. C. F., \& Ferreira, L. S. (2008). Gerenciamento de resultados contábeis por meio de ativos fiscais diferidos. Revista UnB Contábil, 11(1-2), 153169.

Pinheiro, M. A. H. (2008). Cooperativas de crédito: História da evolução normativa no Brasil (6a ed.). Banco Central do Brasil, Brasília. Retrieved from http://www.bcb.gov.br/htms/ public/microcredito/livro_cooperativas_credito. pdf?idioma $=\mathrm{P}$

Portal do Cooperativismo de Crédito (2014). Sistema Raiffeisen. Autor. Retrieved from http:// cooperativismodecredito.coop.br/historia-docooperativismo/sistema-raiffeisen

Portal do Cooperativismo de Crédito (2015). Dados consolidados dos Sistemas Cooperativos. Autor. Retrieved from http://cooperativismodecredito. coop.br/cenario-brasileiro/dados-consolidadosdos-sistemas-cooperativos/

Reis, E. M. (2014). Um estudo empírico do gerenciamento de resultados por meio de decisóes operacionais nas empresas abertas brasileiras (Dissertação de mestrado). Faculdade de Ciências Econômicas, Universidade Federal de Minas Gerais, Minas Gerais, Brasil.

Resolução n. 4.020, de 29 de setembro de 2011. Altera a Resolução n. 3.859, de 27 de maio de 2010, que dispóe sobre a constituição e o funcionamento de cooperativas de crédito. Retrieved from http://www.bcb.gov.br/pre/ normativos/res/2010/pdf/res_3859_v5_P.pdf

Resolução n. 4.243, de 28 de junho de 2013. Altera a Resolução n. 3.859, de 27 de maio de 2010, que dispõe sobre a constituição e o funcionamento de cooperativas de crédito. Retrieved from http:// www.bcb.gov.br/pre/normativos/res/2013/pdf/ res_4243_v1_O.pdf

Rodrigues, A. (2007). Gerenciamento dos resultados contábeis através de receitas e despesas não-operacionais: Estudo empírico das companhias "Nível 1" - BOVESPA . Sociedade, Contabilidade e Gestão, 2(1), 5-18.

Santos, E. C. (2007). Capital regulatório e gerenciamento de resultados nas instituiçóes financeiras que atuam no Brasil (Dissertação de mestrado). Programa de Pós- Graduação em Ciências Contábeis da Fundação Instituto Capixaba de Pesquisas em Contabilidade, Economia e Finanças, Vitória, ES, Brasil. 
Silva, A., Padilha, E. S., \& Silva, T. P. (2015). Análise da performance econômico-financeira das 25 maiores cooperativas de crédito brasileiras. Desenvolvimento em Questão, 13(32), 303-333.

Trueman, B., \& Titman, S. (1988). Explanation of accounting income smoothing. Journal of Accounting Research, 26(Supplement), 127-139.

UNICRED (2014). Sistema UNICRED. Retrieved from http://www.unicred.com.br/
UNICRED (2017). Números UNICRED dezembro 2016. Retrieved from http://www. unicred.com.br/

Zendersky, H. C. (2005). Gerenciamento de resultados em instituiçóes financeiras no Brasil - 2000 a 2004 (Dissertação de mestrado). Programa Multiinstitucional e Inter-Regional de Pós-Graduação em Ciências Contábeis da Universidade de Brasília, Brasília, DF, Brasil. Retrieved from http://www.cca.unb.br/images/ dissert_mest/mest_dissert_076.pdf

\section{Supporting agencies:}

FAPEMIG - Foundation for Research Support of the State of Minas Gerais (Project n.: CSA - APQ-02074-14)

PROBIC/FAPEMIG - Scientific initiation research grant.

\section{About the authors:}

1. Valéria Gama Fully Bressan, PhD in Applied Economics, Federal University of Viçosa, Minas Gerais, Brazil. E-mail: vfully@face.ufmg.br

\section{ORCIID}

D 0000-0001-6340-9717

2. Douglas Coelho de Souza, Bachelor in Accounting Sciences, Federal University of Minas Gerais, Minas Gerais, Brazil. E-mail: douglascoelho.s@hotmail.com

ORCIID

(iD) 0000-0002-8268-9723

3. Aureliano Angel Bressan, PhD in Applied Economics, Federal University of Viçosa, Minas Gerais, Brazil. E-mail: bressan@face.ufmg.br

ORCIID

(iD) 0000-0002-9333-3394

\section{Contribution of each author:}

\begin{tabular}{|c|c|c|c|}
\hline Contribution & $\begin{array}{l}\text { Valéria Gama } \\
\text { Fully Bressan }\end{array}$ & $\begin{array}{l}\text { Douglas Coelho } \\
\text { de Souza }\end{array}$ & $\begin{array}{c}\text { Aureliano Angel } \\
\text { Bressan }\end{array}$ \\
\hline 1. Definition of research problem & $\sqrt{ }$ & & \\
\hline $\begin{array}{l}\text { 2. Development of hypotheses or research questions } \\
\text { (empirical studies) }\end{array}$ & $\sqrt{ }$ & & \\
\hline 3. Development of theoretical propositions (theoretical work) & $\sqrt{ }$ & $\sqrt{ }$ & \\
\hline 4. Theoretical foundation / Literature review & & $\sqrt{ }$ & \\
\hline 5. Definition of methodological procedures & $\sqrt{ }$ & & $\sqrt{ }$ \\
\hline 6. Data collection & $\sqrt{ }$ & & \\
\hline 7. Statistical analysis & $\sqrt{ }$ & & $\sqrt{ }$ \\
\hline 8. Analysis and interpretation of data & $\sqrt{ }$ & $\sqrt{ }$ & $\sqrt{ }$ \\
\hline 9. Critical revision of the manuscript & $\sqrt{ }$ & & $\sqrt{ }$ \\
\hline 10. Manuscript writing & $\sqrt{ }$ & $\sqrt{ }$ & $\sqrt{ }$ \\
\hline
\end{tabular}

